\title{
Panax Notoginseng Saponins Promote Endothelial Progenitor Cell Mobilization and Attenuate Atherosclerotic Lesions in Apolipoprotein E Knockout Mice
}

\author{
Ya Liu ${ }^{a}$ Fei Hao ${ }^{a, b}$ Haigang Zhang ${ }^{c}$ Dayan Cao ${ }^{a}$ Xiaolan Lu ${ }^{d}$ Xiaohui Lia \\ aInstitute of Materia Medica and Department of Pharmaceutics, College of Pharmacy, Third Military \\ Medical University, Chongqing, bDepartment of Medicament and Instrument, No.161 Hospital of PLA, \\ Wuhan, Hubei, 'Department of Pharmacologys, College of Pharmacy, Third Military Medical University, \\ Chongqing, dDepartment of Clinical Laboratory, First Affiliated Hospital of North Sichuan Medical \\ College, Sichuan Nanchong, PR China
}

\section{Key Words}

Atherosclerosis • Panax notoginseng saponins • Endothelial progenitor cell • Mobilization

\begin{abstract}
Background: Endothelial progenitor cells (EPCS) derived from the bone marrow (BM) play a key role in the homeostasis of vascular repair by enhanced reendothelialization. Panax notoginseng saponins (PNS), a highly valued traditional Chinese medicine, has been shown to reduce morbidity and mortality from coronary artery disease. The present research was designed to explore the contribution of progenitor cells to the progression of atherosclerotic plaques and the possible modulatory role of PNS in this process. Methods: PNS (60 or $120 \mathrm{mg}$ / $\mathrm{kg}$ via intraperitoneal injection) was administered over 8 weeks in apolipoprotein $\mathrm{E}$ knockout mice on an atherogenic diet. The sizes and histochemical alteration of atherosclerotic lesions and numbers of EPCs in BM and peripheral blood were analyzed. The expression of chemokine stromal cell-derived factor $1 \alpha$ (SDF-1 $\alpha$ ) and its receptor, CXCR4, was monitored as well. Results: PNS significantly reduced the lesion area and intima-to-media ratio compared to vehicle treatment. PNS also augmented endothelialization and reduced the smooth muscle cell (SMCs) content of the lesions. The number of c-kit and sca-1 double-positive progenitor cells and flk-1 and sca-1 double-positive progenitor cells were significantly increased in the $\mathrm{BM}$ and the peripheral blood of the PNS-treated groups. PNS treatment increased the plasma levels of SDF-1 $\alpha$ and SCF as well as the BM levels of matrix metalloproteinase-9 (MMP-9). Moreover, the mRNA levels of SDF-1 $\alpha$ and protein levels of CXCR4 were both increased in the BM of mice treated with PNS, while SDF-1 $\alpha$ expression decreased. Conclusion: PNS reduce the size of atherosclerotic plaques, and this effect appears to involve progenitor cell mobilization. SDF-1 $\alpha-C X C R 4$ interactions and the possible modulatory role of PNS in this process may contribute to the increased progenitor cell mobilization.
\end{abstract}

Copyright $@ 2013$ S. Karger AG, Basel

Xiaohui Li, PhD 
Liu et al.: Panax Notoginseng Saponins Mobilize Endothelial Progenitor Cells

\section{Introduction}

Atherosclerotic cardiovascular diseases are highly prevalent in Western populations and are the leading cause of death [1]. It is generally accepted that the progressive impairment of endothelial integrity and function constitutes the primum movens of the process, leading to atherosclerotic plaque formation. Therefore, to maintain the integrity of normal endothelium becomes an important therapeutic strategy aimed at reducing the high incidence of atherosclerotic vascular disease. In contrast to the traditional concept that postnatal tissue revascularization is achieved by neighboring endothelial replication, accumulating evidence suggests that endothelial progenitor cells (EPCs), a heterogeneous population of cells that can specifically differentiate into endothelial cells [2], play a key role in the homeostasis of vascular repair by enhanced reendothelialization [3-5]. EPCs have multiple origins, and bone marrow (BM) is the most defined source of circulating EPCs [6]. Several treatments cause a marked increase in the release of BM-derived EPCs into the periphery, a process termed mobilization, which may contribute to increased endothelial repair and reduced atherosclerosis development.

Panax notoginseng (sanqi or tienchi in Chinese), the root of Panax notoginseng (Burk.) F. $\mathrm{H}$. Chen, is a highly valued and important traditional Chinese herb that belongs to the family Araliaceae. Panax notoginseng saponins (PNS) were reported to be the biologically active constituents responsible for the therapeutic action of this medicine. Various reagents of PNS, such as Panax notoginseng saponins Injection (Xue Sai Tong Injection), freeze-drying powder of Panax Notoginseng Saponins for Injection are applied clinically in China and are well established to reduce morbidity and mortality from coronary artery disease [7, 8], meeting the criterion of the Pharmcopoeia of the People's Republic of China 2010. In addition to the lipidlowering effects associated with PNS, our previous studies on the anti-atherogenic effects of PNS have shown that it is capable of reducing vascular inflammation, modulating endothelial dysfunction, and decreasing the formation of foam cells via pleiotropic mechanisms [9-12]. However, the potential role of PNS on EPCs during atherogenesis has not been systematically evaluated. In the present study, we investigated the effects of PNS, administered daily over 8 weeks to apolipoprotein $\mathrm{E}$ knockout (apoE $\mathrm{E}^{-/-}$) mice kept on atherogenic diet by assessing the size and composition of atherosclerotic lesions. The effect of PNS on EPCs contributing to the end othelialization of atherosclerotic lesions was examined. The expression of cytokines and their receptors known to be crucially involved in EPC mobilization was monitored as well.

\section{Materials and Methods}

\section{Chemical standardization of PNS}

A freeze-drying powder of Panax Notoginseng Saponins for Injection (without excipients; PNS content is $100 \%$ ) was purchased from Kunming Pharmaceutical Corporation (Kunming, Yunnan province, China). Standard reagents, including notoginsenoside R1, ginsenoside Rg1 and ginsenoside Rb1 (purity>99\%), were purchased from the National Institute for the Control of Pharmaceutical and Biological Products (Beijing, China). The HPLC analyses of compounds in PNS were performed based on the method established by Zeng et al. [13] with some modification. In brief, the separation was carried out on an Elite LaChrom system (Hitachi, Tokyo, Japan) equipped with a Hypersil C18 column (5 $\mu \mathrm{m}$; length, $200 \mathrm{~mm}$; inside diameter, 4.6 $\mathrm{mm}$, Interchim, Montlucon, France), and the column temperature was maintained at room temperature. A $20 \mu \mathrm{l}$ sample was injected into the column and eluted with a constant flow rate of $1.0 \mathrm{ml} / \mathrm{min}$. The mobile phase consisted of acetonitrile and $\mathrm{H}_{2} \mathrm{O}(25: 75, \mathrm{v} / \mathrm{v}$ ), and a programmable UV detector (Model 526, ESA Inc, Chelmsford, MA) set at $203 \mathrm{~nm}$ was used for the analyses. The data acquisition was performed using the LaChrom Elite software (VWR, Darm Stadt, Germany), and a standard curve was used to calculate the concentrations for samples based on the peak areas. As shown in Fig. 1, the notoginsenoside R1, ginsenoside Rg1 and ginsenoside Rb1 contents in the freeze-dried powder of Panax Notoginseng Saponins for Injection were $0.12 \mathrm{mg}, 0.36 \mathrm{mg}$ and $0.38 \mathrm{mg}$ respectively. 


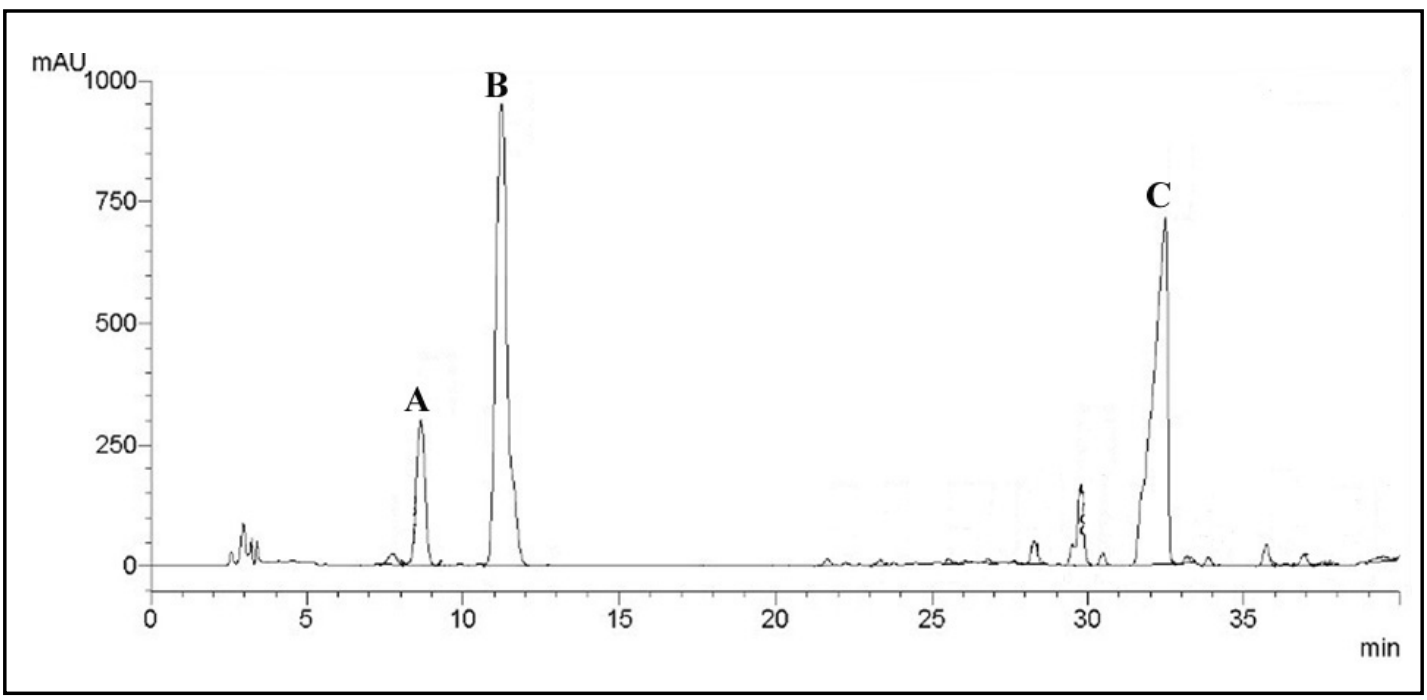

Fig. 1. The chemical standardization of freeze-dried Panax Notoginseng Saponins powder for Injection by HPLC fingerprint analysis. At an absorbance of $203 \mathrm{~nm}$, the peaks corresponding to notoginsenoside R1 (A), ginsenoside Rg1 (B), and ginsenoside Rb1 (C) were identified.

\section{Animal experiments}

Male apoE ${ }^{-/-}$mice (10 weeks of age) were obtained from the Experimental Animal Center of the Third Military Medical University (Chongqing, China). The present study conforms to the Guide for the Care and Use of Laboratory Animals published by the US National Institutes of Health (NIH Publication No. 85-23, revised 1996; http: //www.nap.edu/readingroom/books/labrats/index.html). All protocols were approved by the Ethical Committee for Animal Experimentation of the Third Military Medical University. After a 7-day adaptation period, apoE $\mathrm{E}^{-/-}$mice were fed an atherogenic high fat diet (normal diet supplemented with $0.5 \%$ cholesterol, $10 \%$ yolk powder, and $5 \%$ pork lard) and injected intraperitoneally (i.p.) daily with either a low dose (60 mg/kg; PNS(L); n=20) or high dose (120 mg/kg; PNS(H); n=20) of freeze-drying powder of Panax Notoginseng Saponins for Injection, or vehicle alone $(0.9 \% \mathrm{NaCl}$; Control; $\mathrm{n}=20)$. Drinking water and food were available ad libitum throughout the study. This treatment continued for 8 weeks. At the conclusion of the experiment, animals were fasted overnight and sacrificed under diethyl ether anesthesia for aorta, BM and blood analysis.

\section{Histological and morphometric analysis of atherosclerotic lesions}

The aorta was excised and immediately washed with saline, and the aortic root was cut into $0.5-\mathrm{cm}$ sections, fixed in $10 \%$ buffered formalin. After $24 \mathrm{~h}$, the sections were removed, embedded in paraffin, and performed by hematoxylin-eosin (H\&E) staining and Weigert's staining, respectively. Histopathology alteration was observed by light microscopy and an automated computer based image analysis system (Image Pro Plus, version 4.5; Media Cybernetics, Silver Spring, MD) was applied to conduct the morphometric analysis.

\section{Immunohistochemical analysis of atherosclerotic lesions}

The paraffin-embedded arterial sections were immunostained with a polyclonal rabbit anti- $\alpha$ actin antibody (1:100; Abcam, Cambridge, MA, USA) and a polyclonal rabbit anti-vWF antibody (1:200; Abcam, Cambridge, MA, USA). Labeling was visualized using the streptavidin-biotin-peroxidase method plus diaminobendizine (Dako, Japan) and counterstained with Mayer hematoxylin. The degree of plaque endothelialization was quantified by measuring the length of the vWF-positive endothelial cell layer, and the presence of SMCs in the vessel wall was quantitatively assessed by measuring the area that was immunopositive for $\alpha$-actin antigen within the internal elastic lamina using image analysis software (Image Pro Plus, version 4.5). 
Liu et al.: Panax Notoginseng Saponins Mobilize Endothelial Progenitor Cells

Flow cytometry analysis

BM was harvested by flushing the femurs and tibias with phosphate buffered saline. The blood samples were treated with a lysing solution (BD Bioscience, Heidelberg, Germany). Immunolabeling was performed by incubating cells together with directly conjugated mAbs (rat-anti mouse c-kit -phycoerythrin (PE), Sca1-FITC, flk-1-PE (BD Biosciences, Heidelberg, Germany)) and their corresponding isotype-matched FITC or PE-conjugated rat immunoglobulins for $45 \mathrm{~min}$ at $4{ }^{\circ} \mathrm{C}$ in PBS $/ 0.5 \%$ BSA. The double-stained cells were analyzed with a FACScan flow cytometer (Becton Dickinson, San Jose, CA, USA), and the data were processed using Cell Quest software (Becton Dickinson, San Jose, CA). Each analysis included at least 10,000 events of mononuclear gated cells.

\section{RNA preparation and real-time reverse transcription-PCR}

Total RNA was isolated from the aorta and BM using Tripure reagent (Roche Diagnostics, Mannheim, Germany) according to the manufacturer's instructions. The RNA samples were dissolved in nuclease-free water and treated with $5 \mathrm{U}$ DNase I (Takara, Shiga, Japan) for $30 \mathrm{~min}$ at $37^{\circ} \mathrm{C}$. The reaction was stopped by the addition of $25 \mathrm{mmol} / \mathrm{L}$ EDTA and a 15 -min incubation at $65^{\circ} \mathrm{C}$. The total RNA concentration was quantified by measuring the absorbance at $260 \mathrm{~nm}$. Total RNA $(1 \mu \mathrm{g})$ was reverse transcribed using AMV reverse transcriptase (Promega, Madison, WI, USA) at $42^{\circ} \mathrm{C}$ for $1 \mathrm{~h}$. The PCR primers used were designed by Premier 5.0 (PREMIER Biosoft International, Palo Alto, CA, USA) based on published nucleotide sequences for mouse c-kit (forward: 5'-CTC GGA CAG CAC CAA GCA C-3'; reverse: 5'-GTC GGA GAC AGC AGC AAA GC-3'), mouse SDF- $1 \alpha$ (forward: 5'-CTG TGC CCT TCA GAT TGT TGC-3'; reverse: 5'-TGG GCT GTT GTG CTT ACT TGT T-3'), mouse SCF (forward: 5'-AGG CTC ATC CGC TCT GTA GTT-3'; reverse: 5'-TAT GCC GTG GTA TTA TGC TGC-3) and mouse $\beta$-actin (forward: 5'-GGC TGT ATT CCC CTC CAT CG-3'; reverse: 5'-CCA GTT GGT AAC AAT GCC ATG T-3). Each real-time PCR reaction was carried out in triplicate in a total volume of $20 \mu \mathrm{l}$ with the Quanti Tect SYBR Green PCR Master Mix (MJ Research, Waltham, MA, USA) using the following conditions: 5 min at $95^{\circ} \mathrm{C}, 40$ cycles at $95^{\circ} \mathrm{C}$ for $10 \mathrm{~s}$, annealing for $15 \mathrm{~s}\left(63^{\circ} \mathrm{C}, 63^{\circ} \mathrm{C}, 62^{\circ} \mathrm{C}, 62^{\circ} \mathrm{C}\right.$, for c-kit, SDF- $1 \alpha$, SCF and $\beta$-actin, respectively), $72{ }^{\circ} \mathrm{C}$ for $20 \mathrm{~s}$, and $82.5^{\circ} \mathrm{C}$ for $5 \mathrm{~s}$ (collecting fluorescence) with the ABI Prism 7700 sequence detection system (ABI, Oyster Bay, NY, USA). After amplification, a melting curve analysis was performed by collecting fluorescence data while increasing the temperature from $72{ }^{\circ} \mathrm{C}$ to $99^{\circ} \mathrm{C}$ over $135 \mathrm{~s}$. The $\mathrm{Ct}$ (cycle threshold) values were normalized to the expression levels of $\beta$-actin.

Enzyme-linked immunosorbent assay test

Blood plasma was obtained by the centrifugation of blood at $4^{\circ} \mathrm{C}$ and $1500 \times \mathrm{g}$ for $20 \mathrm{~min}$, and the $\mathrm{BM}$ was processed as previously described [14]. According to the manufacturer's instructions, an enzymelinked immunosorbent assay (ELISA) (R\&D Systems, USA) was performed to determinate SDF-1, SCF and MMP-9 levels in $100 \mu \mathrm{l}$ of undiluted plasma or BM samples.

\section{Western blot analysis}

BM cells were resuspended in $100 \mu \mathrm{l}$ of lysis buffer (Cell Signaling Technology, Boston, MA, USA), sonicated and cleared by centrifugation at $3000 \mathrm{rpm}$ for $10 \mathrm{~min}$ at $4{ }^{\circ} \mathrm{C}$. Equal amounts of protein $(60$ $\mu \mathrm{g}$ ) were fractionated by electrophoresis on a $10 \%$ SDS polyacrylamide gel together with molecular weight standards and then transferred to nitrocellulose membranes (Roche, Indianapolis, IN, USA). The membranes were blocked in 3\% non-fat dry milk (in TBS) prior to incubation with rabbit anti-SDF-1 $\alpha$ antibody (1:1000; Abcam, Cambridge, MA, USA) or rabbit anti-CXCR4 antibody (1:1000; Abcam, Cambridge, MA, USA) overnight at $4{ }^{\circ} \mathrm{C}$. The proteins were visualized with HRP-conjugated anti-rabbit IgG (1:2500; Dako, Denmark) followed by chemiluminescent detection and autoradiography (Fuji Medical X-Ray Film, Tokyo, Japan).

\section{Statistical analysis}

The data are expressed as the mean \pm SD. The statistical significance of differences between the group means was determined by a one-way ANOVA (SPSS 13.0, Chicago, IL, USA). $P<0.05$ was considered significant. 


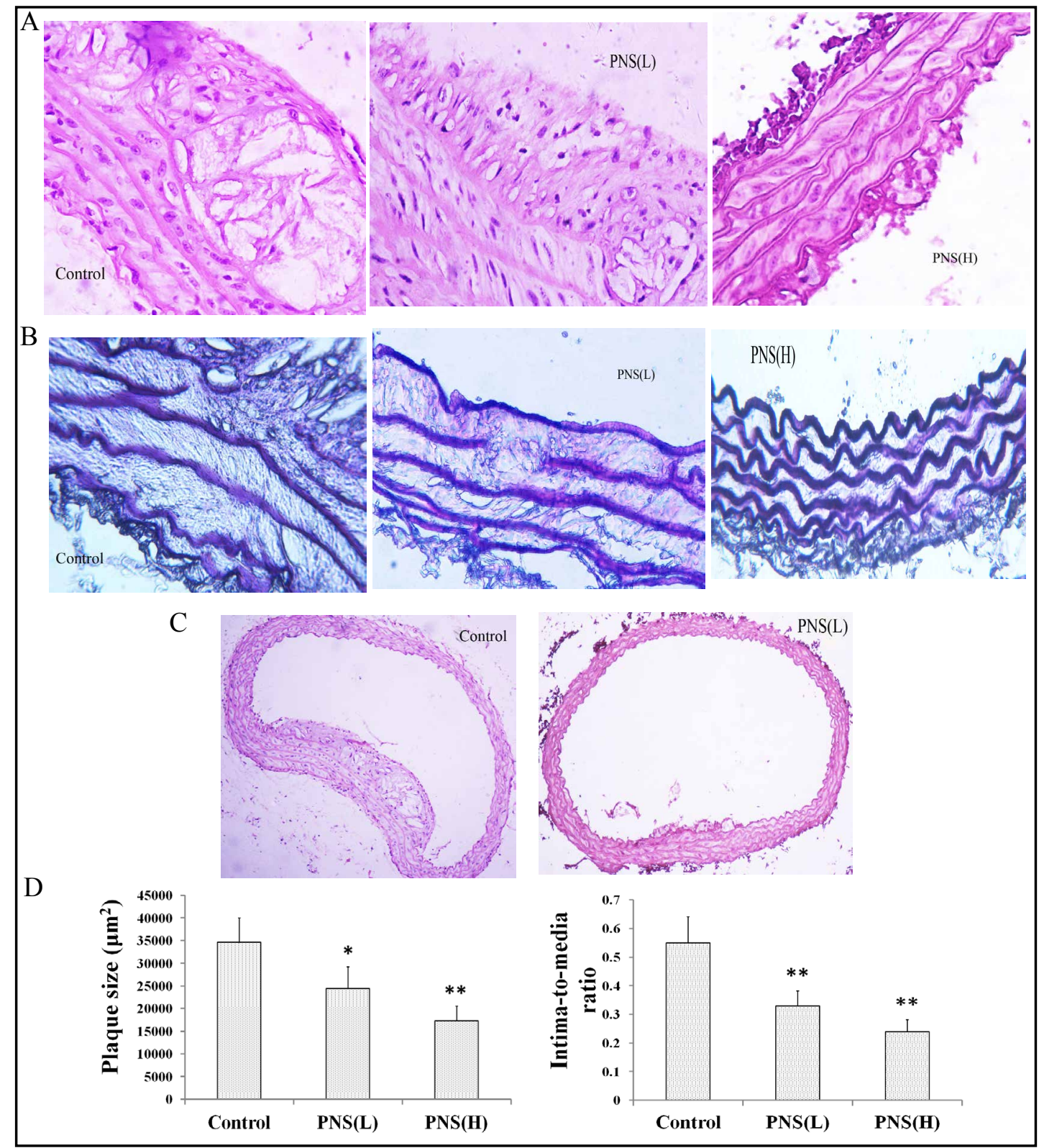

Fig. 2. The effect of PNS on atherosclerotic lesion formation. (A) Histopathologic observation of atherosclerotic pathology alteration in aortas (H\&E Staining); (B) Elastic fiber layers alteration in aortas (Weigert's staining); Magnification, 400×. (C) Representative images of atherosclerotic lesions in the aortic root in the Control and PNS (H) group (H\&E staining); Magnification, 100×. (D) Morphometric analysis of the atherosclerotic plaque area and the intima-to-media ratio. The data are presented as the mean \pm SD. $n=5$ in each group. ${ }^{*} \mathrm{P}<0.05,{ }^{* *} \mathrm{P}<0.01$ versus Control (One-way ANOVA). Control group, apoE ${ }^{-/-}$mice were fed an atherogenic high fat diet and injected daily with $0.9 \% \mathrm{NaCl}$ intraperitoneally (i.p.); PNS (L) group, apoE $\mathrm{E}^{-/-}$mice $^{-1}$ were fed an atherogenic high fat diet and injected daily with $60 \mathrm{mg} / \mathrm{kg}$ PNS intraperitoneally (i.p.); PNS (H) group, apoE ${ }^{-/-}$mice were fed an atherogenic high fat diet and injected daily with $120 \mathrm{mg} / \mathrm{kg}$ PNS intraperitoneally (i.p.).

\section{Results}

PNS attenuates atherosclerotic lesion and increases endothelialisation

After fed with an atherogenic diet for 8 weeks, the aortic root of apoE $\mathrm{E}^{-/}$mice exhibited typical atherosclerotic alteration, including an irregular lumen, impairment and 
Fig. 3. The immunohistochemical analysis of atherosclerotic lesions. (A) The vWFimmunopositive cell stain in aortas. (B) The $\alpha$-actin-positive SMCs stain in aortas. Magnification, 400×. The results of the quantitative analysis of vWF-immunopositive cell distance and the content of $\alpha$-actinpositive SMCs in atherosclerotic lesion are also shown. The data are presented as the mean \pm SD. $n=5$ in each group. ${ }^{*} \mathrm{P}<0.05$, ${ }^{* *} \mathrm{P}<0.01$ versus Control (One-way ANOVA).Control group, apoE $E^{-/-}$mice were fed an atherogenic high fat diet and injected daily with $0.9 \% \mathrm{NaCl}$ intraperitoneally (i.p.); PNS (L) group, apoE $\mathrm{E}^{-/-}$mice were fed an atherogenic high fat diet and injected daily with 60 $\mathrm{mg} / \mathrm{kg}$ PNS intraperitoneally (i.p.); PNS (H) group, apoE $\mathrm{E}^{-/-}$mice were fed an atherogenic high fat diet and injected daily with 120 $\mathrm{mg} / \mathrm{kg}$ PNS intraperitoneally (i.p.).

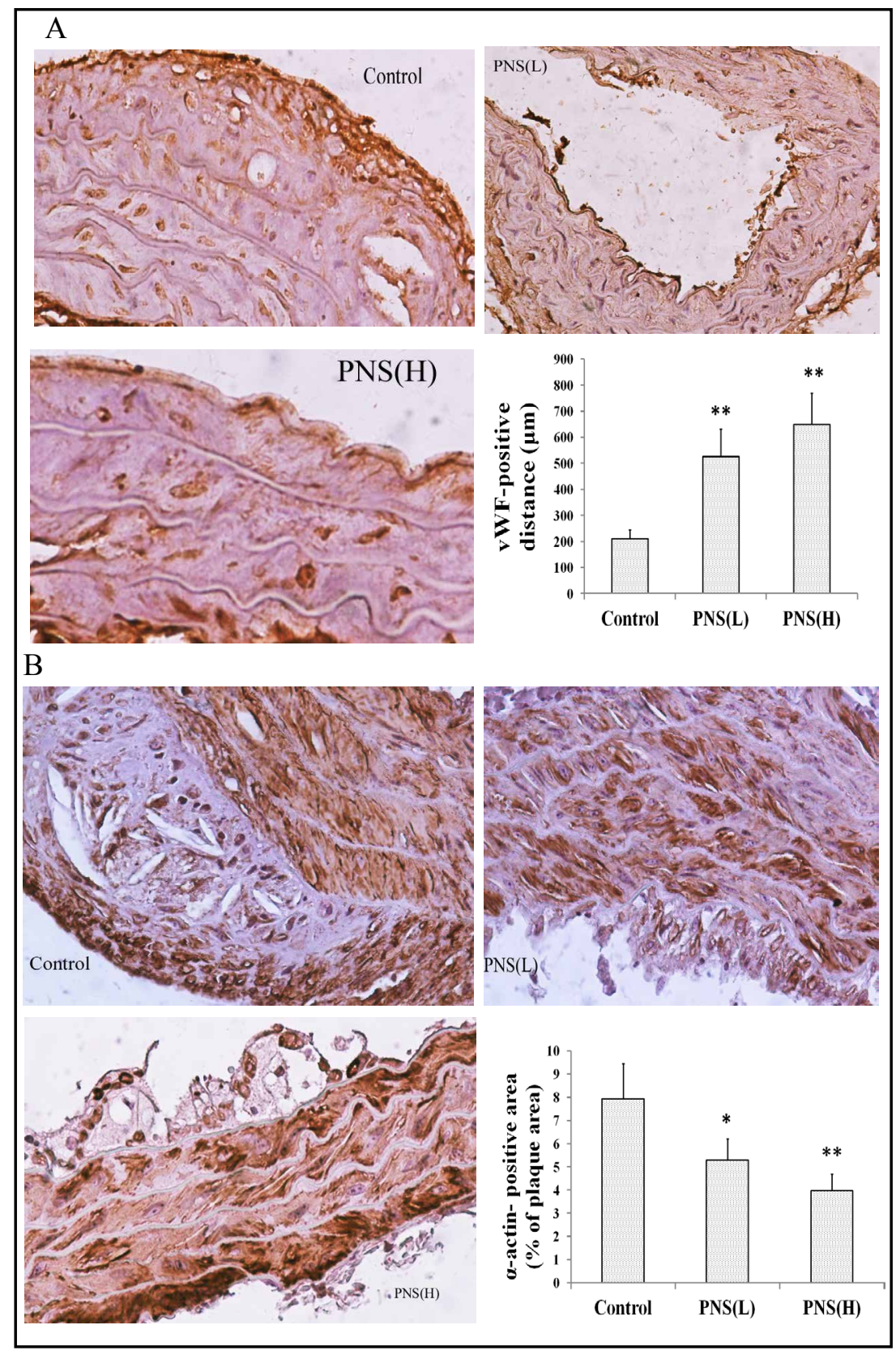

desquamation of endothelial cells, thickening of the endarterium, aggregation of foam cells under endarterium, attenuation of tunica media, proliferation of SMA, and unclear even broken elastic fiber layers. In the $60 \mathrm{mg} / \mathrm{kg}$ PNS-treated group, the pathological changes observed were less serious than that in control group. In the $120 \mathrm{mg} / \mathrm{kg}$ PNS-treated group, however, only a portion of endarterium was slightly thickened. (Fig. 2A, B)

PNS dose-dependently reduced the atherosclerotic lesion area at the aortic root from $34580 \pm 5400 \mu \mathrm{m}^{2}$ in the vehicle-treated group to $24380 \pm 4800 \mu \mathrm{m}^{2}$ in the $60 \mathrm{mg} / \mathrm{kg}$ PNStreated group $(P<0.05)$ and $17239 \pm 3347 \mu \mathrm{m}^{2}$ in the $120 \mathrm{mg} / \mathrm{kg}$ PNS-treated group $(P<$ $0.01)$. Similarly, the intima-to-media ratio was reduced from $0.55 \pm 0.091$ in the vehicletreated group to $0.33 \pm 0.052$ in the $60 \mathrm{mg} / \mathrm{kg}$ PNS-treated group $(P<0.01)$ and $0.24 \pm 0.041$ in the $120 \mathrm{mg} / \mathrm{kg}$ PNS-treated group $(P<0.01)$ (Fig. 2 C,D) 


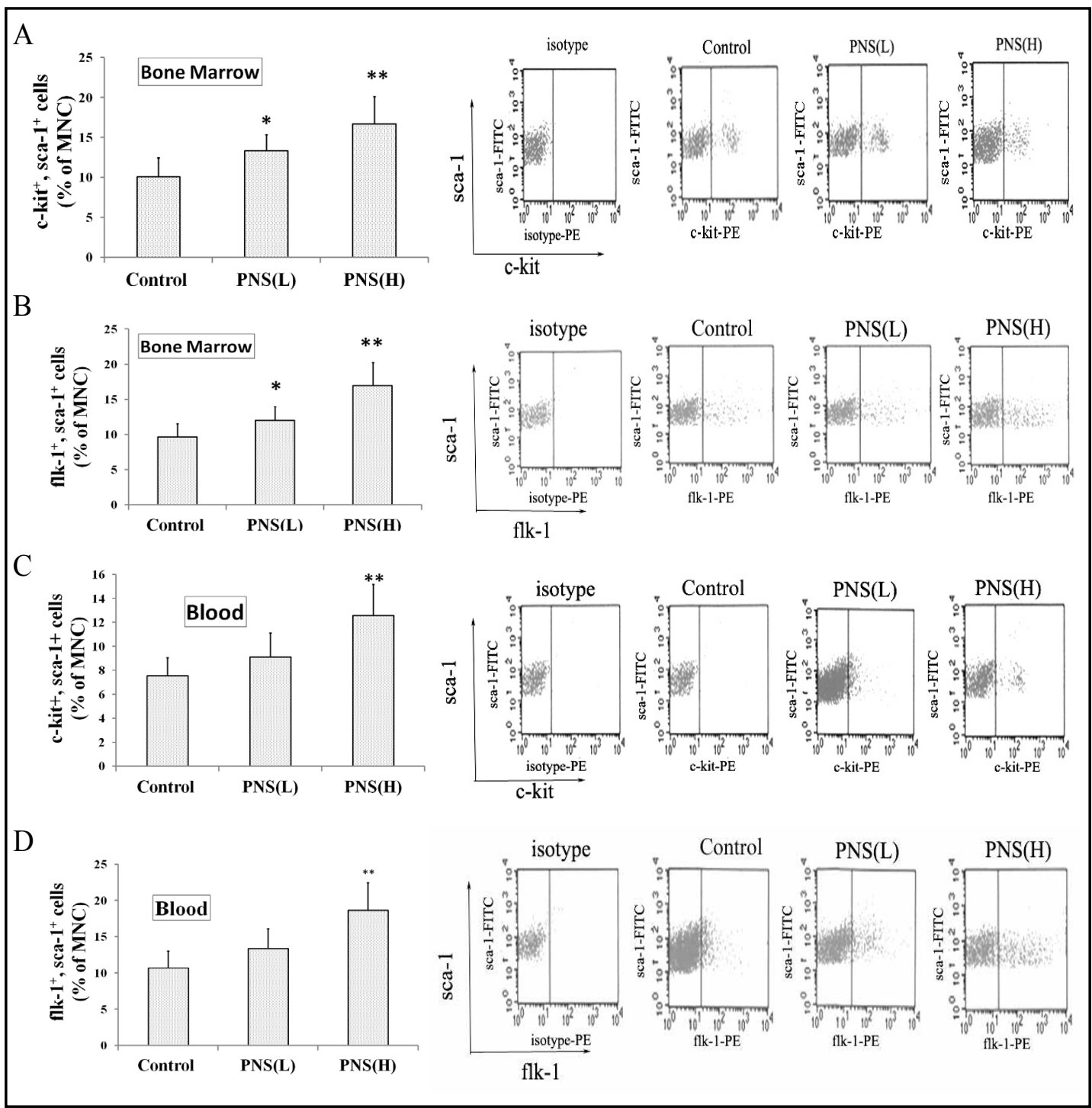

Fig. 4. PNS enhances progenitor cell mobilization from the bone marrow. Flow cytometry analysis was performed to determine the number of c-kit and sca-1 double-positive progenitor cells or sca-1 and flk-1 double-positive progenitor cells in the BM (A, B) and blood (C, D). The data are presented as the mean \pm SD. $\mathrm{n}=7$ in each group. ${ }^{*} \mathrm{P}<0.05,{ }^{* *} \mathrm{P}<0.01$ versus Control (One-way ANOVA). Control group, apoE ${ }^{-/-}$mice were fed an atherogenic high fat diet and injected daily with $0.9 \% \mathrm{NaCl}$ intraperitoneally (i.p.); PNS (L) group, apo $E^{-/-}$mice were fed an atherogenic high fat diet and injected daily with $60 \mathrm{mg} / \mathrm{kg}$ PNS intraperitoneally (i.p.); PNS (H) group, apoE ${ }^{-/-}$mice were fed an atherogenic high fat diet and injected daily with $120 \mathrm{mg} / \mathrm{kg}$ PNS intraperitoneally (i.p.).

The quantification of luminal vWF-immunopositive cells revealed that treatment with both 60 and $120 \mathrm{mg} / \mathrm{kg}$ PNS augmented plaque endothelialization $(P<0.01$ vs. Control $)$ (Fig. 3A). The lesions from $60(P<0.05$ vs. Control) and $120 \mathrm{mg} / \mathrm{kg}(P<0.01$ vs. Control) PNS-treated mice were also characterized by reduced $\alpha$-actin-positive SMC content in aorta (Fig. 3B).

PNS promotes the mobilization of progenitor cells from the bone marrow

$\mathrm{BM}$ and peripheral blood were analyzed using flow cytometry to determine whether treatment with PNS affects the mobilization of BM-derived progenitor cells during atherogenesis. Because currently there is no conclusive marker for EPCs, it is believed that the 


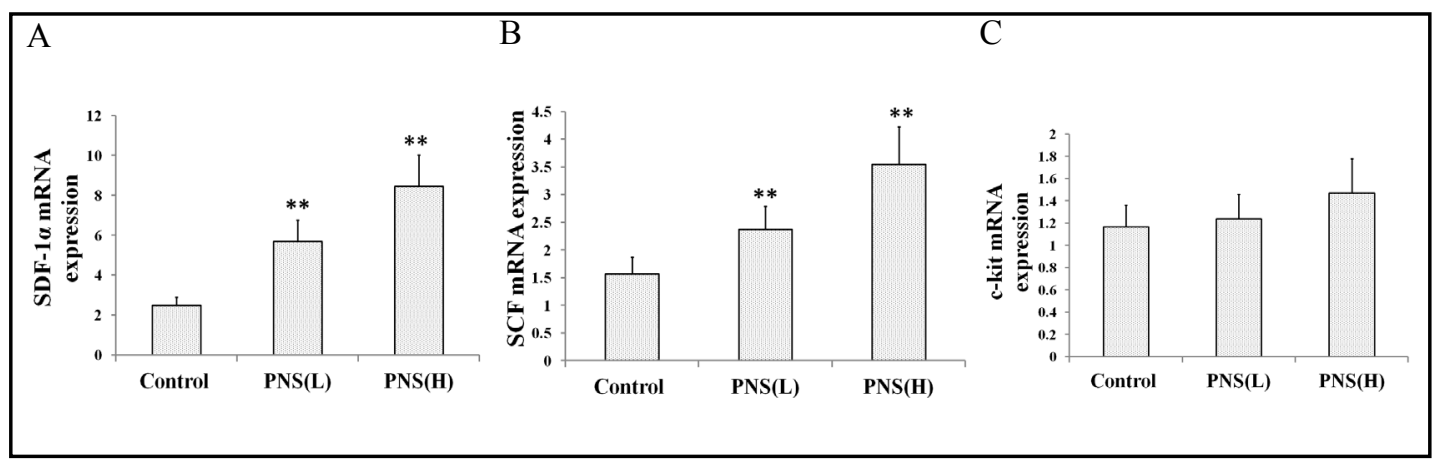

Fig. 5. The effect of PNS on the mRNA expressions of SDF-1 $\alpha$ (A), SCF (B) and c-kit (C) in BM. The data are presented as the mean \pm SD. $n=5$ in each group. ${ }^{*} \mathrm{P}<0.05,{ }^{* *} \mathrm{P}<0.01$ versus Control (One-way ANOVA). Control group, apoE $\mathrm{E}^{-/-}$mice were fed an atherogenic high fat diet and injected daily with $0.9 \% \mathrm{NaCl}$ intraperitoneally (i.p.); PNS (L) group, apoE ${ }^{-/-}$mice were fed an atherogenic high fat diet and injected daily with $60 \mathrm{mg} / \mathrm{kg}$ PNS intraperitoneally (i.p.); PNS (H) group, apoE $\mathrm{E}^{-/-}$mice were fed an atherogenic high fat diet and injected daily with $120 \mathrm{mg} / \mathrm{kg}$ PNS intraperitoneally (i.p.).

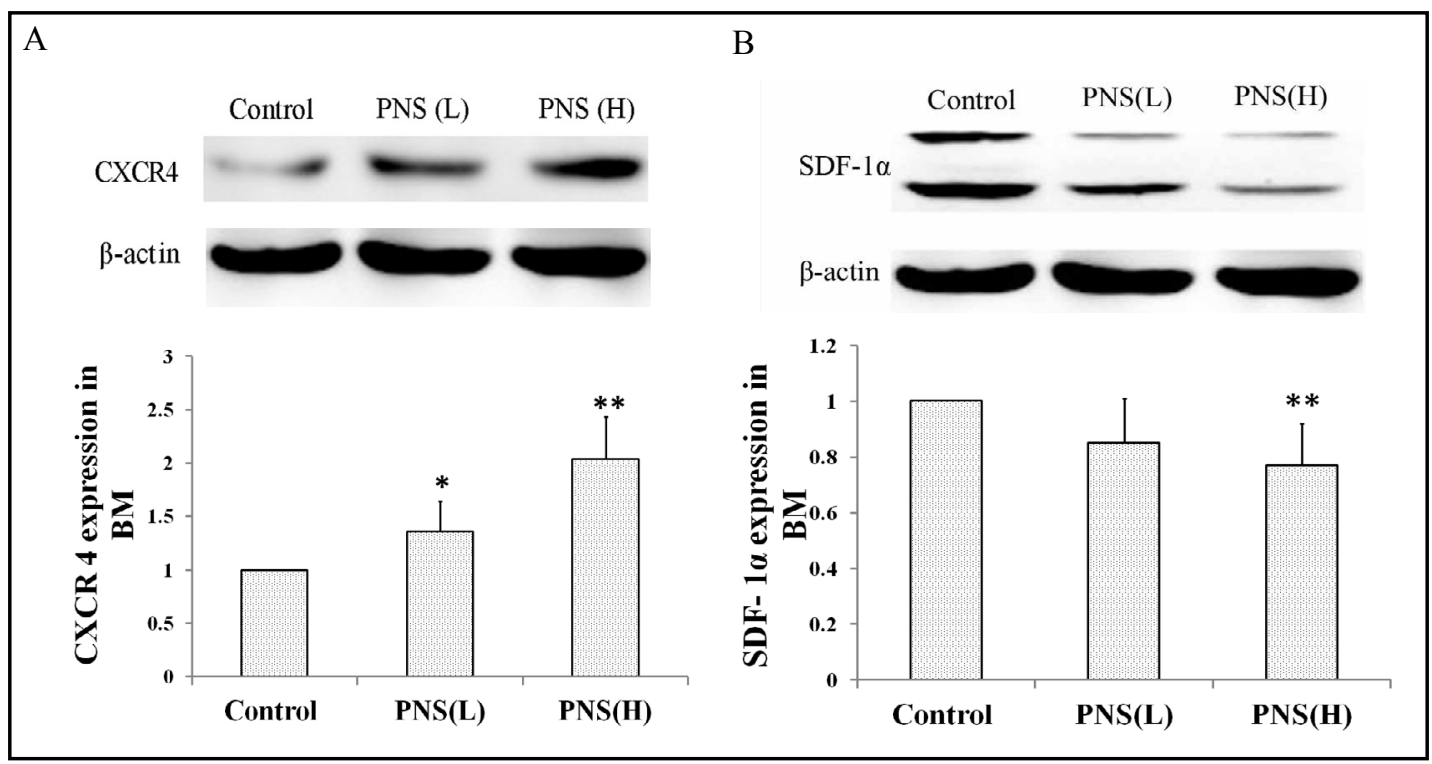

Fig. 6. The effect of PNS on the expression of CXCR4 and SDF- $1 \alpha$ in BM. Western blot analysis of CXCR4 (A) and SDF-1 $\alpha$ (B). The results of the quantitative analysis (expressed as percent of total, protein with the Control group set at 1 ) of CXCR 4 and SDF- $1 \alpha$ are shown below each blot. The data are presented as the mean \pm SD. $\mathrm{n}=5$ in each group. ${ }^{*} \mathrm{P}<0.05,{ }^{* *} \mathrm{P}<0.01$ versus Control (One-way ANOVA). Control group, apoE ${ }^{-/-} \mathrm{mice}^{-}$ were fed an atherogenic high fat diet and injected daily with $0.9 \% \mathrm{NaCl}$ intraperitoneally (i.p.); PNS (L) group, apoE $\mathrm{E}^{-/-}$mice were fed an atherogenic high fat diet and injected daily with $60 \mathrm{mg} / \mathrm{kg}$ PNS intraperitoneally (i.p.); PNS (H) group, apoE $\mathrm{E}^{-/-}$mice were fed an atherogenic high fat diet and injected daily with 120 $\mathrm{mg} / \mathrm{kg}$ PNS intraperitoneally (i.p.).

cells could be EPCs if they are double positive for both markers of progenitor and endothelial cells. As for mice, EPC surface marker combinations such as stem cell antigen-1(sca-1) ${ }^{+}$ VEGFR2 (flk-1 for rodents) ${ }^{+}$and c-kit ${ }^{+} /$flk- $1^{+}$have been widely used to characterize EPCs [15-17]. In the present study, we found a significant increase in the proportion of c-kit and sca-1 double-positive cells in the $120 \mathrm{mg} / \mathrm{kg}$ PNS-treated group compared to the vehicletreated group in both the BM $(P<0.01)$ (Fig. $4 \mathrm{~A})$ and the peripheral blood $(P<0.01)$ (Fig. $4 \mathrm{C})$. However, this change was only detected in the BM $(P<0.05)$ of $60 \mathrm{mg} / \mathrm{kg}$ PNS-treated mice (Fig. 4 A). The proportion of flk- 1 and sca- 1 double-positive cells was significantly 


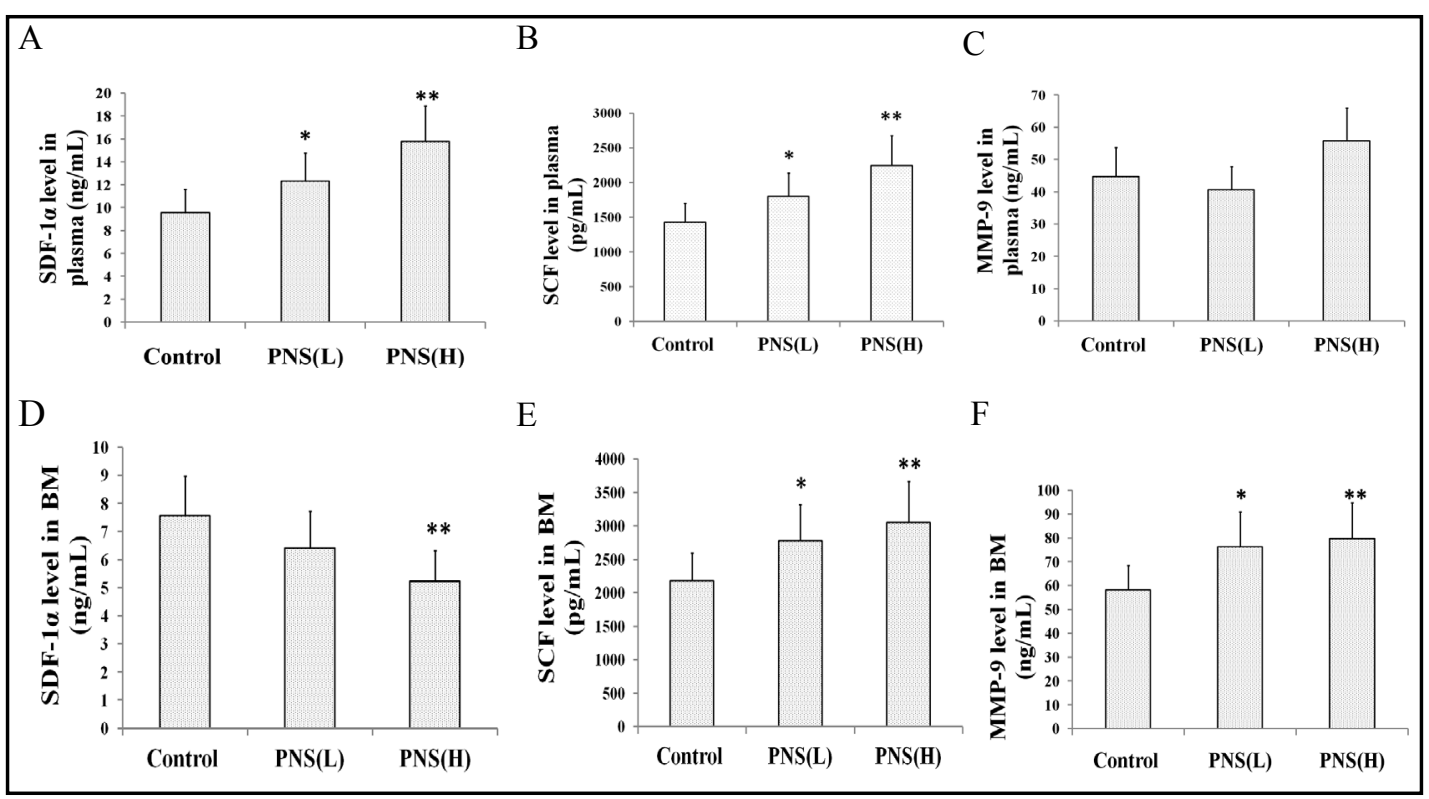

Fig. 7. The effect of PNS on the level of SDF-1 $\alpha$, SCF and MMP-9 in plasma and BM. An enzyme-linked immunosorbent assay for SDF-1 $\alpha$, SCF and MMP-9 in plasma (A, B, C) and BM (D, E, F). The data are presented as the mean \pm SD. $n=7$ in each group. ${ }^{*} \mathrm{P}<0.05,{ }^{*} \mathrm{P}<0.01$ versus Control (One-way ANOVA). Control group, $\mathrm{apoE}^{-/-}$mice were fed an atherogenic high fat diet and injected daily with $0.9 \% \mathrm{NaCl}$ intraperitoneally (i.p.); PNS (L) group, apo: $\mathrm{E}^{-/-}$mice were fed an atherogenic high fat diet and injected daily with $60 \mathrm{mg} / \mathrm{kg}$ PNS intraperitoneally (i.p.); PNS (H) group, apoE $\mathrm{E}^{-/-}$mice were fed an atherogenic high fat diet and injected daily with $120 \mathrm{mg} / \mathrm{kg}$ PNS intraperitoneally (i.p.).

increased in the $120 \mathrm{mg} / \mathrm{kg}$ PNS-treated mice compared to the vehicle-treated mice in both the BM $(P<0.01)$ (Fig. 4 B) and the peripheral blood $(P<0.01)$ (Fig. 4 D), while this increase was only detected in the BM $(P<0.05)$ of the $60 \mathrm{mg} / \mathrm{kg}$ PNS-treated mice (Fig. $4 \mathrm{~B})$.

\section{Messenger RNA Expressions of SDF-1 $\alpha$, SCF and c-kit in BM}

BM homogenates were analyzed for the mRNA expression of factors known to be involved in stem cell mobilization. The mRNA expression of SDF-1 $\alpha$ (Fig. $5 \mathrm{~A}$ ) and the SCF (Fig. 5 B) were both significantly increased in 60 and $120 \mathrm{mg} / \mathrm{kg}$ PNS-treated mice compared to vehicle-treated mice $(\mathrm{P}<0.01)$. However, the mRNA expression of c-kit in BM did not differ significantly between the treatment groups (Fig. 5 C).

\section{Expressions of CXCR4 and SDF- $1 \alpha$ in $B M$}

Western blot analysis of the BM homogenates indicated an increase in the expression of CXCR4 in $120 \mathrm{mg} / \mathrm{kg}$ and $60 \mathrm{mg} / \mathrm{kg}$ PNS-treated mice (P < 0.01 or 0.05 ) (Fig. 6A), whereas treatment with $120 \mathrm{mg} / \mathrm{kg}$ PNS appeared to decrease SDF-1 $\alpha$ expression significantly by comparison of that of vehicle-treated mice $(\mathrm{P}<0.01)$ (Fig. $6 \mathrm{~B}$ )

\section{The level of SCF, SDF- $1 \alpha$ and MMP-9 in plasma and BM}

Finally, the analyses of the SDF- $1 \alpha$, SCF and MMP-9 levels in plasma and BM revealed significantly elevated plasma SDF- $1 \alpha$ (Fig. 7 A) and SCF (Fig. 7 B) levels in mice treated with $60 \mathrm{mg} / \mathrm{kg}(P<0.05)$ and $120 \mathrm{mg} / \mathrm{kg}$ PNS $(P<0.01)$ compared with those in vehicle-treated mice. Plasma MMP-9 levels were similar and did not differ significantly between all the groups (Fig. 7 C). We also found the levels of SDF- $1 \alpha$, SCF and MMP-9 elevated significantly $(P<0.01$; Fig. 7 D, E, F) in the BM of $120 \mathrm{mg} / \mathrm{kg}$ PNS-treated mice, whereas treatment with $60 \mathrm{mg} / \mathrm{kg}$ PNS only elevated the levels of SCF and MMP-9 $(P<0.05)$ compared to vehicletreated mice. 
Liu et al.: Panax Notoginseng Saponins Mobilize Endothelial Progenitor Cells

\section{Discussion}

In the present study, we evaluated the effects of daily treatment with PNS on the size and composition of atherosclerotic plaques and the mobilization of BM-derived EPCs during atherosgenesis in hypercholesterolaemic apoE ${ }^{-/-}$mice. In accordance with our previous findings in rabbit and rat experiments $[9,18]$, satisfactory anti-atherogenic effect of PNS on apoE $\mathrm{E}^{-/-}$mice was observed, displaying decreased size of aortic plaques, reduced ratio of intima-to-media, and alleviation of atherosclerotic pathological changes in arteries. Moreover, the quantitative analysis revealed that PNS treatment was associated with a reduction in intralesional SMCs, particularly in the high-dose PNS-treated mice. In this regard however, the effect of PNS on foam cells and SMCs might have contributed to its effect on plaque reduction $[11,19]$. Interestingly, PNS treatment in the present study was found to enhance lesion endothelialization and rapid reendothelialization, which may effectively attenuate the aggregation of foam cells, proliferation of SMCs, and limit the extent of atherosclerotic plaque formation after vascular injury $[20,21]$. All these suggested that effect of PNS at least partly resulted from enhancing lesion endothelialisation.

By performing flow cytometry analyses of blood and BM, we found that PNS treatment significantly increased the number of c-kit and sca- 1 double-positive cells, the most primitive murine hematopoietic stem cells with multi-lineage potential, and the more differentiated fraction of flk-1 and sca-1 double-positive endothelial progenitor cells. Our findings also appear to show a pronounced effect of the high PNS dose compared to the low dose on the amount of EPCs in the BM and peripheral blood. The present data, namely the increase in EPC numbers, suggest a novel mechanism for PNS in enhancing progenitor mobilization from the BM. It is notable, however, that a single measurement of circulating EPC counts has prognostic implications, with low EPC levels associated with future cardiovascular events, such as stroke, acute coronary syndromes, heart failure, and even peripheral artery diseases $[22,23]$. Accordingly, increasing the number of circulating EPCs has been shown to improve the neovascularization of ischemic hindlimbs, accelerate blood flow in diabetic mice, and improve cardiac function [24-27]. Other parallel lines of evidence have advanced the idea that BM-derived EPCs might be a source of the cells responsible, at least in part, for endothelial repair during the development of atherosclerosis [28-30]. Although the presence of BM-derived EPCs in atherosclerotic lesions remains to be confirmed directly, it is suggested that the mobilization of BM-derived EPCs by PNS may significantly contribute to atherosclerotic lesion regression.

The regulation of EPC mobilization from BM is a highly complex and interdependent process. Stromal cell-derived factor-1 (SDF-1) has been the primary focus of attention among the key players. The predominant isoform, SDF- $1 \alpha$, and its receptor, CXC chemokine receptor 4 (CXCR4), which are expressed at high levels for both vascular and hematopoietic progenitor cells, are of great importance in steady-state homeostatic processes within BM. In the present study, the increase in EPCs following PNS treatment is at least equipotent compared with the SDF-1 $\alpha /$ CXCR4 axis, which is known to promote EPC mobilization in vitro and after gene transfer in vivo [31-34]. Analysis of the molecular pathways revealed that PNS treatment profoundly increased plasma SDF- $1 \alpha$ levels, and evidence supporting the increased levels of plasma SDF-1 $\alpha$ were significantly correlated with an elevated number of circulating EPCs $[35,36]$. Of note, the SDF-1 $\alpha$ level within the BM after PNS treatment for 8 weeks was significantly reduced in our study, indicating a possible dependence between the local and systemic changes in the levels of SDF-1 $\alpha$. Furthermore, several studies have shown that a newly formed gradient of SDF- $1 \alpha$ towards the blood circulation is sufficient to induce stem cell mobilization [37, 38]. Decreased BM SDF-1 $\alpha$ was further confirmed by western blot analysis, whereas high mRNA expression of SDF- $1 \alpha$ was clearly detected after high-dose PNS treatment, which led us to the hypothesis that SDF- $1 \alpha$ may be degraded by proteolytic cleavage and various matrix metalloproteinase (MMPs), including MMP-2 and MMP-9 [3941]. The reduction of SDF- $1 \alpha$ concentrations within the BM may interfere with retention and facilitate the egress of cells, which may suggest that a high degradation of BM SDF-1 $\alpha$ is 
required for the egress of progenitors. Consistent with our data, another study has shown a reduction of BM SDF-1 during cyclophosphamide and G-CSF mobilization in mice [42].

SDF- $1 \alpha$ may not only promote the transfer of hematopoietic stem cells from a quiescent to a proliferative niche by mechanisms involving the activation of MMP-9 but may also induce the secretion of MMP-9 in BM $[2,43]$. MMP-9 was also shown to cleave the membrane-bound Kit ligand (mKitL) and induce the release of soluble Kit ligand (KitL; also known as stem cell factor, SCF). Subsequently, sKitL induces the release of more SDF-1 $\alpha$, enhancing the mobilization of $\mathrm{CXCR}^{+}$and c-Kit ${ }^{+}$cells into circulation [44]. In this regard, the MMP-9 level in the BM as well as the SCF level in the plasma and BM were significantly unregulated in mice treated with PNS. On the other hand, effects of PNS on the mRNA expression levels of SCF, but not c-kit, within the BM were detected. In addition, we observed that PNS induced the up-regulation of BM CXCR4 expression during atherogenesis. The up-regulation of CXCR4 may serve to increase the sensitivity of cells to lower SDF- $1 \alpha$ signals, which could be a consequence of the potent collapse of SDF- $1 \alpha$ concentrations within the BM or induced by cytokines, such as SCF [44]. The present study suggests the regulation of SDF-1 $\alpha$ and CXCR4 in the BM as targets for PNS to mobilize the BM-derived EPCs. Accumulating evidence has indicated that the SDF- $1 \alpha$-CXCR4 pathway also regulates several crucial aspects during the recruitment of progenitor cells to sites of vascular injury [45]. In the present study, we found that PNS significantly up-regulates the expression of SDF- $1 \alpha$ and increases the number of CXCR4-positive cells within the vessel wall (not shown). However, further research is required to elucidate these mechanisms.

In conclusion, our study reveals new mechanistic insights into the capacity of PNS to protect $\mathrm{apoE}^{-/-}$mice from atherosclerosis, as characterized by a higher degree of endothelialization. These involve BM-derived EPC mobilization, a major role played by SDF$1 \alpha-C X C R 4$ interactions, and the possibility that PNS may have contributed to increased progenitor cell mobilization. Overall, this finding may shed light on the pharmacologic principles of the clinical use of PNS in the treatment of atherosclerosis.

\section{Acknowledgements}

This study was supported by the National Natural Science Foundation of China $\left(\mathrm{N}^{\circ} 81001663\right)$.

\section{References}

1 Go AS, Mozaffarian D, Roger VL, Benjamin EJ, Berry JD, Borden WB, Bravata DM, Dai S, Ford ES, Fox CS, Franco S, Fullerton HJ, Gillespie C, Hailpern SM, Heit JA, Howard VJ, Huffman MD, Kissela BM, Kittner SJ, Lackland DT, Lichtman JH, Lisabeth LD, Magid D, Marcus GM, Marelli A, Matchar DB, McGuire DK, Mohler ER, Moy CS, Mussolino ME, Nichol G, Paynter NP, Schreiner PJ, Sorlie PD, Stein J, Turan TN, Virani SS, Wong ND, Woo D, Turner MB; American Heart Association Statistics Committee and Stroke Statistics Subcommittee: Executive summary: heart disease and stroke statistics--2013 update: a report from the American Heart Association. Circulation 2013;127:143-152.

-2 Urbich C, Dimmeler S: Endothelial progenitor cells: characterization and role in vascular biology. Circ Res 2004;95:343-353.

-3 Young PP, Vaughan DE, Hatzopoulos AK: Biological properties of endothelial progenitor cells and their potential for cell therapy. Prog Cardiovasc Dis 2007;49:412-429.

4 Werner N, Junk S, Laufs U, Link A, Walenta K, Bohm M, Nickenig G: Intravenous transfusion of endothelial progenitor cells reduces neointima formation after vascular injury. Circ Res 2003;93:e17-24.

5 Griese DP, Ehsan A, Melo LG, Kong D, Zhang L, Mann MJ, Pratt RE, Mulligan RC, Dzau VJ: Isolation and transplantation of autologous circulating endothelial cells into denuded vessels and prosthetic grafts: implications for cell-based vascular therapy. Circulation 2003;108:2710-2715. 
Liu et al.: Panax Notoginseng Saponins Mobilize Endothelial Progenitor Cells

6 Hu Y, Davison F, Zhang Z, Xu Q: Endothelial replacement and angiogenesis in arteriosclerotic lesions of allografts are contributed by circulating progenitor cells. Circulation 2003;108:3122-3127.

7 Gan LJ, Zhang CH, Zhang M: Effect of intracoronary injection with xuesaitong in treating post-PCI slowreflow phenomenon in patients with ST-segment elevation myocardial infarction. Zhongguo Zhong Xi Yi Jie He Za Zhi 2010;30:348-351.

8 Liu X, Li J, Yang G, Wang J: Study on effect of promoting blood circulation drugs components in treating unstable angina in patients with blood stasis inflammatory levels. 2008;33:2950-2953.

-9 Liu Y, Zhang HG, Jia Y, Li XH: Panax notoginseng saponins attenuate atherogenesis accelerated by zymosan in rabbits. Biol Pharm Bull 2010;33:1324-1330.

-10 Fan JS, Liu DN, Huang G, Xu ZZ, Jia Y, Zhang HG, Li XH, He FT: Panax notoginseng saponins attenuate atherosclerosis via reciprocal regulation of lipid metabolism and inflammation by inducing liver $\mathrm{X}$ receptor alpha expression. J Ethnopharmacol 2012;142:732-738.

11 Jia Y, Li ZY, Zhang HG, Li HB, Liu Y, Li XH: Panax notoginseng saponins decrease cholesterol ester via upregulating ATP-binding cassette transporter A1 in foam cells. J Ethnopharmacol 2010;132:297-302.

12 He CY, Li XH, Li SH, He XF: Protective effect of total Saponins of panax notognseng on vascular endothelial cell against injury induced by oxidized low density lipoprotein. China Pharmacy 2008;19:401-403.

13 Zeng RH, Deng XM, Lu HX, Mo ZJ, Liu Y: Determination the contents of Panax Notoginseng Saponins in Compound Danshen Tablets by HPLC. Guide of China Medicine 2010;8:21-23.

14 Xu Q, Wang J, He J, Zhou M, Adi J, Webster KA, Yu H: Impaired CXCR4 expression and cell engraftment of bone marrow-derived cells from aged atherogenic mice. Atherosclerosis 2011;219:92-99.

15 Jackson KA, Majka SM, Wang H, Pocius J, Hartley CJ, Majesky MW, Entman ML, Michael LH, Hirschi KK, Goodell MA: Regeneration of ischemic cardiac muscle and vascular endothelium by adult stem cells. J Clin Invest 2001;107:1395-1402.

16 Daniel JM, Bielenberg W, Stieger P, Weinert S, Tillmanns H, Sedding DG: Time-course analysis on the differentiation of bone marrow-derived progenitor cells into smooth muscle cells during neointima formation. Arterioscler Thromb Vasc Biol 2010;30:1890-1896.

17 Gao D, Nolan DJ, Mellick AS, Bambino K, McDonnell K, Mittal V: Endothelial progenitor cells control the angiogenic switch in mouse lung metastasis. Science 2008;319:195-198.

18 Y Zhang YG, Zhang HG, Zhang GY, Fan JS, Li XH, Liu YH, Li SH, Lian XM, Tang Z: Panax notoginseng saponins attenuate atherosclerosis in rats by regulating the blood lipid profile and an anti-inflammatory action. Clin Exp Pharmacol Physiol 2008;35:1238-1244.

19 Xu L, Liu JT, Liu N, Lu PP, Pang XM: Effects of Panax notoginseng saponins on proliferation and apoptosis of vascular smooth muscle cells. J Ethnopharmacol 2011;137:226-230.

-20 Leppänen 0, Rutanen J, Hiltunen MO, Rissanen TT, Turunen MP, Sjöblom T, Brüggen J, Bäckström G, Carlsson M, Buchdunger E, Bergqvist D, Alitalo K, Heldin CH, Ostman A, Ylä-Herttuala S: Oral imatinib mesylate (STI571/gleevec) improves the efficacy of local intravascular vascular endothelial growth factor-C gene transfer in reducing neointimal growth in hypercholesterolemic rabbits. Circulation 2004;109:1140-1146.

21 Hillebrands JL, Klatter FA, van den Hurk BM, Popa ER, Nieuwenhuis P, Rozing J: Origin of neointimal endothelium and alpha-actin-positive smooth muscle cells in transplant arteriosclerosis. J Clin Invest 2001;107:1411-1422.

-22 Schmidt-Lucke C, Rössig L, Fichtlscherer S, Vasa M, Britten M, Kämper U, Dimmeler S, Zeiher AM: Reduced number of circulating endothelial progenitor cells predicts future cardiovascular events: proof of concept for the clinical importance of endogenous vascular repair. Circulation 2005;111:2981-2987.

23 Morishita T, Uzui H, Nakano A, Mitsuke Y, Geshi T, Ueda T, Lee JD: Number of endothelial progenitor cells in peripheral artery disease as a marker of severity and association with pentraxin-3, malondialdehydemodified low-density lipoprotein and membrane type-1 matrix metalloproteinase. J Atheroscler Thromb 2012;19:149-158.

24 Galasso G, De Rosa R, Ciccarelli M, Sorriento D, Del Giudice C, Strisciuglio T, De Biase C, Luciano R, Piccolo R, Pierri A, Di Gioia G, Prevete N, Trimarco B, Piscione F, Iaccarino G: $\beta 2$-Adrenergic Receptor Stimulation Improves Endothelial Progenitor Cell-Mediated Ischemic Neoangiogenesis. Circ Res 2013;112:1026-1034.

-25 Iwaguro H, Yamaguchi J, Kalka C, Murasawa S, Masuda H, Hayashi S, Silver M, Li T, Isner JM, Asahara T: Endothelial progenitor cell vascular endothelial growth factor gene transfer for vascular regeneration. Circulation 2002;105:732-738. 
Liu et al.: Panax Notoginseng Saponins Mobilize Endothelial Progenitor Cells

26 Schatteman GC, Hanlon HD, Jiao C, Dodds SG, Christy BA: Blood-derived angioblasts accelerate blood-flow restoration in diabetic mice. J Clin Invest 2000;106:571-578.

27 Westenbrink BD, Lipsic E, van der Meer P, van der Harst P, Oeseburg H, Du Marchie Sarvaas GJ, Koster J, Voors AA, van Veldhuisen DJ, van Gilst WH, Schoemaker RG: Erythropoietin improves cardiac function through endothelial progenitor cell and vascular endothelial growth factor mediated neovascularization. Eur Heart J 2007;28:2018-2027.

28 Rauscher FM, Goldschmidt-Clermont PJ, Davis BH, Wang T, Gregg D, Ramaswami P, Pippen AM, Annex BH, Dong C, Taylor DA: Aging, progenitor cell exhaustion, and atherosclerosis. Circulation 2003;108:457-463.

-29 Miller-Kasprzak E, Jagodziński PP: Endothelial progenitor cells as a new agent contributing to vascular repair. Arch Immunol Ther Exp (Warsz) 2007;55:247-259.

-30 Zampetaki A, Kirton JP, Xu Q: Vascular repair by endothelial progenitor cells. Cardiovasc Res 2008;78:413421.

-31 Yin Y, Zhao X, Fang Y, Yu S, Zhao J, Song M, Huang L: SDF-1alpha involved in mobilization and recruitment of endothelial progenitor cells after arterial injury in mice. Cardiovasc Pathol 2010;19:218-227.

-32 Bogoslovsky T, Spatz M, Chaudhry A, Maric D, Luby M, Frank J, Warach S; NINDS Natural History of Stroke Investigators: Stromal-derived factor-1[alpha] correlates with circulating endothelial progenitor cells and with acute lesion volume in stroke patients. Stroke 2011;42:618-625.

33 Walter DH, Haendeler J, Reinhold J, Rochwalsky U, Seeger F, Honold J, Hoffmann J, Urbich C, Lehmann R, Arenzana-Seisdesdos F, Aicher A, Heeschen C, Fichtlscherer S, Zeiher AM, Dimmeler S: Impaired CXCR4 signaling contributes to the reduced neovascularization capacity of endothelial progenitor cells from patients with coronary artery disease. Circ Res 2005;97:1142-1151.

-34 Dimmeler S: Regulation of bone marrow-derived vascular progenitor cell mobilization and maintenance. Arterioscler Thromb Vasc Biol 2010;30:1088-1093.

-35 Hattori K, Heissig B, Tashiro K, Honjo T, Tateno M, Shieh JH, Hackett NR, Quitoriano MS, Crystal RG, Rafii S, Moore MA: Plasma elevation of stromal cell-derived factor- 1 induces mobilization of mature and immature hematopoietic progenitor and stem cells. Blood 2001;97:3354-3360.

-36 Xiao Q Kiechl S, Patel S, Oberhollenzer F, Weger S, Mayr A, Metzler B, Reindl M, Hu Y, Willeit J, Xu Q: Endothelial progenitor cells, cardiovascular risk factors, cytokine levels and atherosclerosis--results from a large population-based study. PLoS One 2007;2:e975.

37 De Falco E, Porcelli D, Torella AR, Straino S, Iachininoto MG, Orlandi A, Truffa S, Biglioli P, Napolitano M, Capogrossi MC, Pesce M: SDF-1 involvement in endothelial phenotype and ischemia-induced recruitment of bone marrow progenitor cells. Blood 2004;104:3472-3482.

38 Lamagna C, Bergers G: The bone marrow constitutes a reservoir of pericyte progenitors. J Leukoc Biol 2006;80:677-668.

39 Petit I, Szyper-Kravitz M, Nagler A, Lahav M, Peled A, Habler L, Ponomaryov T, Taichman RS, ArenzanaSeisdedos F, Fujii N, Sandbank J, Zipori D, Lapidot T: G-CSF induces stem cell mobilization by decreasing bone marrow SDF-1 and up-regulating CXCR4. Nat Immunol 2002;3:687-694 .

40 McQuibban GA, Butler GS, Gong JH, Bendall L, Power C, Clark-Lewis I, Overall CM: Matrix metalloproteinase activity inactivates the CXC chemokine stromal cell-derived factor-1. J Biol Chem 2001;276:43503-43508.

41 Abbott JD, Huang Y, Liu D, Hickey R, Krause DS, Giordano FJ: Stromal cell-derived factor-1alpha plays a critical role in stem cell recruitment to the heart after myocardial infarction but is not sufficient to induce homing in the absence of injury. Circulation 2004;110:3300-3305.

42 Lévesque JP, Hendy J, Takamatsu Y, Simmons PJ, Bendall LJ: Disruption of the CXCR4/CXCL12 chemotactic interaction during hematopoietic stem cell mobilization induced by GCSF or cyclophosphamide. J Clin Invest 2003;111:187-196.

43 Sen S, McDonald SP, Coates PT, Bonder CS: Endothelial progenitor cells: novel biomarker and promising cell therapy for cardiovascular disease. Clin Sci (Lond) 2011;120:263-283.

44 Heissig B, Hattori K, Dias S, Friedrich M, Ferris B, Hackett NR, Crystal RG, Besmer P, Lyden D, Moore MA, Werb Z, Rafii S: Recruitment of stem and progenitor cells from the bone marrow niche requires MMP-9 mediated release of kit-ligand. Cell 2002;109:625-637.

45 Yamaguchi J, Kusano KF, Masuo O, Kawamoto A, Silver M, Murasawa S, Bosch-Marce M, Masuda H, Losordo DW, Isner JM, Asahara T: Stromal cell-derived factor-1 effects on ex vivo expanded endothelial progenitor cell recruitment for ischemic neovascularization. Circulation 2003;107:1322-1328. 